\title{
SIR ARTHUR KEITH CENTENARY
}

\author{
W. R. LeFanu, London, England \\ Librarian, Royal College of Surgeons of England
}

Sir Arthur Keith was born a hundred years ago on February 5, 1866, and lived and worked till he was eighty-nine. He made valuable contributions in many fields of anatomy, but will always be remembered as a great teacher. Fifty years ago, at the middle of his career as conservator of the Hunterian Museum at the Royal College of Surgeons, his name was known to thousands who knew nothing of the College or its museum and little enough of Keith's scientific work. They knew him because he was one of the last of the great Victorian popularisers. He believed profoundly that whatever he knew ought to be made widely known. Keith has told in his autobiography that when appointed conservator in 1908 he found that " it had become a tradition for the College Museum to make headway under its own momentum." He determined to make it a centre for discovery and the spread of knowledge.

When Keith came to the College he had made his mark during twelve years as a most successful teacher of anatomy at the London Hospital. He had published a textbook, Human Embryology and Morphology (1898), which was written with the wide outlook of an anthropologist and comparative anatomist. This book proved popular with successive generations of students, and Keith himself revised its sixth edition fifty years after its first appearance. Most notably he had published a series of papers on the functional anatomy of the heart, which marked a real advance. His discovery of the sino-atrial node, shared with his pupil Martin Flack, had been made known in 1907.

Keith determined to attract young surgeons to work in the college museum and acquire a scientific basis of surgery. Later he inspired the

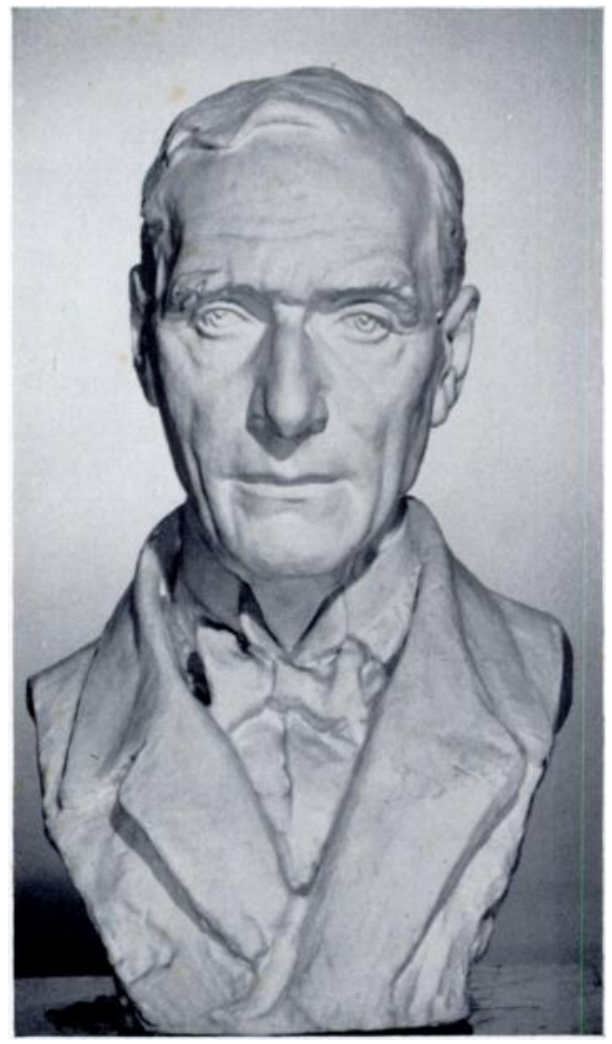

Sir Arthur Keith, F.R.S. $1866-1955$

Bust by Malvina Hoffman

By permission of the Royal College of Surgeons of England idea of the Surgical Research Institute at Downe, which Lord Moynihan as president of the College promoted and Sir Buckston Browne endowed. Under Keith's direction it proved a fertile nursery of scientific surgery.

Recalling his first years at the College just before the first world war, Keith wrote: "I wanted to enlist the help of the 20,000 fellows and members of the College, and I wanted the museum and its conservator to have behind their efforts not only the weight of medical opinion but also that of the educated public." The editors of medical and scientific journals were ready to help but he found lay journalists profoundly ignorant of science and therefore he said: "when I wanted public help, I became my own journalist." Keith was always alert to what was being done around him. He wrote: "I have made it a habit to assimilate as I go along the hundreds of researches of a kind similar to my own which are issued every year 
from laboratories at home and abroad." At first he used this knowledge to keep students abreast of current advances; then he wanted to tell the world also, and to give not only the facts but his own view of the facts. It was a time when there was an eager audience for "prophets." Bernard Shaw and H. G. Wells, Keith's exact contemporary, were offering the millennium; Russell and Whitehead the mathematicians, Lodge the physicist and Jeans the astronomer were all writing for the general public. Keith, too, believed that a medical scientist, with his direct human interest, must propagate his knowledge and opinions.

He had the gift of an easy and attractive style. In his lectures he was almost conversational; with questions and short sentences and hesitations of delivery he seemed to draw his audience in, as if he and they were thinking and discovering together. In his writings he preferred vivid pictorial phrases. For he had an artist's sensibility and a keen delight in the charm of tradition. "Sentiment has its place in science," he wrote, " not in the laboratory, but in the heart of the worker." Again and again we find that, when he was studying a problem, he looked back to those who had tilled the field before him.

All these aspects of his genius were displayed to advantage in his book on the bases and background of orthopaedic surgery, Menders of the Maimed (1919). This remarkable book is at the same time a wide-ranging history of orthopaedics and an informed critique of surgical procedures. It grew out of a course of lectures which Keith had given, under a more academic title, at the Royal College through the winter of 1917-18. At that moment the innumerable casualties of the first world war were providing surgical problems and opportunities on an unprecedented scale, particularly in the treatment of bone injuries. Keith's book discussed such subjects as " bone-setting " and " sprain-rubbing," bone growth and grafting, regeneration of nerves, movement versus rest, tenotomy and tendon transplantation, illustrating each topic by an account of the pioneers in each field, such as Hunter and Stromeyer, W. J. Little and H. O. Thomas, Sayre and Redfern, Lucas-Champonnière and Arbuthnot Lane, and evaluating their contributions to the advance of knowledge and treatment.

Throughout his life Keith sought to formulate the evolutionary history of the human body. In his early years in the Far East, where he had gone as doctor and botanist, he made comparative studies on the musculature of apes and monkeys, which he recorded in the text and drawings of his unpublished M.D. thesis and in numerous special papers. During his years as a lecturer at the London Hospital his interest turned to teratology, and he made extensive studies of malformations of the viscera. Indeed, his work on the heart was a special aspect of this wider research. Later at the Royal College of Surgeons he became widely accepted as a one-man "court of appeal " in questions of physical anthropology during the decades between the wars when fossil human and anthropoid remains were being reported from many countries, including China and Africa.

If we open Keith's chief anthropological work, The Antiquity of Man, in the revised edition of 1925 where he surveyed and analysed these discoveries, the first words we read are "Consider the Garden of Eden": strange words to introduce a serious scientific book. " The Garden of Eden has often been described before," Keith wrote. "Long ago an account of it appeared in the Pentateuch; quite lately it has been described in Back to Methuselah. The story told here takes the reader not to a single sunlit idyllic glade, but to dank and dark caves, gravel pits, limestone quarries, excavations for new docks, trenches cut for sewage pipes, all the world over. The Garden of Eden was world wide. Nor was the drama of the Garden enacted in a single morning. The drama of man's evolution, his 'creative evolution,' as Mr Shaw insists on naming it, was not staged for a single performance-it is still proceeding in our slums and palaces, just as it did when man's only roof was the wide dome of the sky." The drama of man's evolution: that was the ear-catching phrase Keith used for the scientific problem which most fascinated him throughout his long life.

On this problem he gave his presidential address to the British Association in 1927, and published it under the title " Concerning man's origin." He spoke deliberately to the world at 
large; he mentioned "the marvel of wireless which makes my voice heard by thousands." He described himself here as a " post-Darwinian." He proclaimed that Darwin's position was impregnable. Darwin's Descent of Man, published fifty years earlier, was still the best account of human evolution. But the new evidence accumulated since Darwin's time needed explanation and interpretation, just as Huxley had explained and interpreted the original evidence. Keith's first-hand knowledge of human physical evolution was profound, but he was also a man of strong opinions and feelings. He extended his view of physical human evolution to psychological problems of ethics and politics, where his knowledge and equipment were much less securely based. He was quite right to point out that his fellow rationalists were too hopeful in thinking that prejudice, hatred and war would wither away under the cold wind of reason, but this involved him in controversy on two fronts, against the fundamentalists and against the dreamers of dreams. He enjoyed controversy, but he was not quarrelsome. He could be dignified, but was never self-important or pompous, for he had a vein of dry Scottish humour and mischief. He was essentially modest and friendly; he loved his fellow men and treated them all, the famous man and the beginner, with the same charming courtesy.

The controversial aspect of his journalism brought him into some disrepute, but his popular writing did not lower his scientific standards. All the time, while he was writing essays for the press, he went on with his serious work. When in 1948, at the age of eighty-two, he published for the general reader his New Theory of Human Evolution, he also brought out a revised edition of his textbook of Embryology, equipped with detailed reference to the latest work in that field. The historical vision which he displayed in Menders of the Maimed inspired much of his other work. He liked to recall that Darwin's teaching on the "Descent of Man " had been foreshadowed by Sir William Lawrence in his Hunterian Lectures at the Royal College of Surgeons in 1819. He expounded the contribution made to science by his predecessors in the conservatorship, William Clift and Richard Owen, whom he considered the greatest of comparative anatomists. At the very end of his life, when he was eighty-eight, he completed a book on Darwin's life and work, and after half a lifetime's intimacy with the Hunterian Collection he repeated the words he had written when he was appointed conservator: "The more I know of John Hunter, the more he grows in stature." When his ephemeral controversies are forgotten, the same will be said of Arthur Keith. 